\title{
STUDI PEMBUATAN MINUMAN ISOTONIK BERBAHAN BAKU AIR KELAPA TUA (COCOS NICIFERA L) DAN EKSTRAK BELIMBING WULUH (AVVERHOA BILIMBI L) MENGGUNAKAN METODE STERILISASI NON-THERMALSELAMA PENYIMPANAN
}

\section{(Study Of Making Isotonic Drinks Based Raw Old Coconut Water (Cocos nucifera L) And Extract Of Star fruit (Avverhoa bilimbi L) By Using Sterilization non-Thermal For Storage)}

\author{
Jumriah Langkong ${ }^{1 *)}$, Nandi K Sukendar ${ }^{1)}$, dan Zulfikar Ihsan ${ }^{1)}$ \\ ${ }^{1 *}$ Program Studi Ilmu dan Teknologi Pangan Departemen Teknologi Pertanian Universitas Hasanuddin \\ Makassar, Indonesia \\ *)email Penulis Korespondensi: jumriah_langkong@yahoo.com
}

\begin{abstract}
ABSTRAK
Minuman isotonik adalah salah satu jenis minuman yang berfungsi untuk menggantikan cairan tubuh yang hilang karena aktivitas fisik. Minuman ini terbuat dari bahan baku air kelapa dan ekstrak "wuluh" belimbing wangi dengan tambahan gula. Air kelapa digunakan dari kelapa matang secara optimal dan belimbing muda "wuluh". Formulasi bahan dilakukan dengan air kelapa sebanyak 88\%, ekstrak "wuluh" belimbing 5\%, dan penambahan gula sebanyak 7\%. Minuman isotonik disiapkan dengan mengekstraksi "wuluh" belimbing dan menyiapkan kelapa sebelum mencampur semua bahan. Perlakuan tersebut disaring menggunakan filter mikro (0,5 dan 0,1 mikron) dan tanpa penyaringan. Proses pencampuran bahan dilakukan secara higienis untuk memperoleh produk yang layak. Berdasarkan pengujian visualisasi produk dengan menggunakan alat filter bisa lebih lama daripada tanpa alat filter.
\end{abstract}

Kata Kunci: minuman isotonic, air kelapa, belimbing

\begin{abstract}
Isotonic drinks is one type of beverages that serves to replace body fluids lost due to physical activity. The drink is made from raw materials of coconut water and extract "wuluh" starfruit with the addition of sugar. Coconut water used from an optimally mature of coconut and young "wuluh" starfruit. The material formulation was conducted with coconut water as much as 88\%, extract "wuluh" starfruit 5\%, and the addition of sugar as much as 7\%. Isotonic beverage was prepared by extracting "wuluh" starfruit and preparing coconut before mixing all ingredients. The treatment was filtering using by micro filter $(0.5$ and 0.1 micron) and without filtering. The mixing process of the material was carried out hygienically to obtain a viable product. Based on product visualization testing by using a filter tool can longer than without a filter tool.
\end{abstract}

Keywords : Isotonik Drink, Coconut water, star fruit

\section{PENDAHULUAN}

Minuman merupakan suatu produk pangan yang memiliki berbagai macam manfaat untuk tubuh. Di Indonesia, terdapat berbagai produk minuman yang telah ada, baik berupa minuman isotonik, sirup, maupun dalam bentuk jus. Banyaknya produk minuman yang beredar dipasaran tentu masyarakat harus jeli dalam memilih produk minuman yang baik. Salah satu minuman yang berfungsi bagi kesehatan manusia adalah minuman isotonik.

Komponen yang terkandung dalam minuman isotonikini adalah mineral sebagai pengganti elektrolit yang hilang, 
gula sebagai sumber energi bagi tubuh, dan tambahan asam organik alami yang berfungsi penambah kebugaran bagi tubuh. Dengan banyaknya studi mengenai minuman isotonik maka sangat aman untuk dikonsumsi. Perkembangan minuman isotonik di pasaran menjadi sangat pesat dikarenakan banyaknya jenis minuman isotonik yang sudah memenuhi standar untuk dikonsumsi.

Kelapa adalah salah satu buah tropis yang memiliki manfaat bagi tubuh. Keseluruhan pada buah kelapa dapat dimanfaatkan dalam pengolahan pangan mulai dari pohon, daun, buah, hingga airnya.Air kelapa merupakan salah satu produk dari tanaman kelapa yang belum banyak dimanfaatkan, padahal air kelapa banyak mengandung kalori, protein, dan mineral yang sangat dibutuhkan oleh tubuh. Karena pemanfaatannya masih terbatas maka, sering kali air kelapa ini dibuang begitu saja, baik ke sungai atau parit pembuangan (sarmidi, 2009). Padahal air kelapa dapat diolah menjadi nata de coco, asam cuka, jelly, saus, alkohol, sirup, kecap, gula kelapa, minuman ringan seperti isotonikdan sebagainya (Rindegan, 2004). Beberapa penelitian terdahulu telah banyak dilakukan tentang air kelapa untuk pengembangan dan pemanfaatan dari air kelapa ini, seperti penelitian (Riyana, 2002), yang mengkaji penggunaan bahan pengawet dan suhu selama penyimpanan air kelapa terhadap mutunya sebagai minuman isotonik.

Belimbing merupakan salah satu buah yang memiliki jenis varietas yang bermacam - macam.Salah satu jenis belimbing yang paling banyak digunakan yaitu belimbing wuluh.Belimbing wuluh adalah jenis buah tropis yang buahnya berwarna hijau kekuningan dan memiliki rasa yang asam. Belimbing wuluh biasanya dimanfaatkan sebagai penyedap rasa pada masakan dan sebagai penyegar dalam beberapa jenis makanan.Buahini dalam 100 gr mengandung 36 kalori. Buah ini juga mengandung beberapa vitamin seperti vitamin A, B, dan C. (Winarno, 2002).
Setiap 100 g pada belimbing wuluh segar mengandung air 92,9 g; vitamin C $35 \mathrm{mg}$; dan fosfor $13 \mathrm{mg}$ (Fachruddin, 2002). Pemanfaatan belimbing wuluh pada pengolahan pangan masih sangat sedikit dikarenakan kurangnya ilmu pengetahuan mengenai kandungan dan manfaat dari belimbing wuluh.

Minuman air kelapa tua dan ekstrak belimbing wuluh ini merupakan salah satu minuman isotonik dengan penerapan pengetahuan untuk memanfaatkan air kelapa tua dan belimbing wuluh sebagai bahan baku. Minuman isotonik yang terbuat dari air kelapa tua dan ekstrak belimbing wuluh ini memiliki manfaat yaitu untuk menggantikan ion yang hilang dalam tubuh akibat aktivitas fisik yang dilakukan. Cairan dalam minuman isotonik, memiliki tekanan sama dengan dinding pembuluh darah, yang menyebabkan minuman ini lebih mudah diserap oleh tubuh daripada air biasa. Minuman ini juga memiliki kandungan elektrolit yang sama dengan yang dikeluarkan tubuh saat berkeringat. Berdasarkan uraian di atas maka dilakaukan penelitian pembuatan minuman isotonik dengan memanfaatkan air kelapa tua dan belimbing wuluh untuk meningkatkan nilai ekonomi dan sebagai pengetahuan baru. Rumusan masalah pada penelitian ini yaitu:. Bagaimana cara membuat minuman isotonic yang disukai oleh masyarakat umum dengan tetap menjaga kandungan dan fungsi dari minuman tersebut, Air kelapa tua dan belimbing wuluh merupakan bahan pangan yang kurang dimanfaatkan sehingga dibutuhkan upaya untuk memanfaatkan dan menambah nilai ekonomis dengan mengkombinasikannya dalam pembuatan minuman isotonic, Penggunaan saringan untuk sterilisasi nonthermal dengan menggunakan mikrofilrasi masih terbatas pada air mineral sehingga dibutuhkan upaya untuk pengaplikasian yang lebih pada pembuatan minuman atau produk lainnya dan sterilisasi thermal dapat mengurangi mutu pada produk pangan sehingga dibutuhkan teknik sterilisasi non- 
thermal untuk mencegah kerusakan mutu pada bahan pangan.

Tujuan dari penelitian ini adalah:

Untuk mengetahui kandungan yang terdapat pada minuman isotonic yang dihasilkan dan untuk mengetahui tingkat kesukaan panelis terhadap minuman kombinasi isotonik dari air kelapa tua dan belimbing wuluh.

Kegunaan yang diharapkan dari penelitian ini adalah sebagai sarana untuk mengembangkan wawasan mengenai pemanfaatan segala jenis tanaman pangan untuk diolah menjadi produk pangan yang memiliki manfaat bagi tubuh dan nilai ekonomis yang tinggi.

\section{METODOLOGI PENELITIAN}

\subsection{Alat}

Alat yang digunakan pada penelitian ini yaitu penyaring mikrofiltrasi, timbangan analitik, erlenmeyer, bulp, pipet volume, blender, wadah, saringan, botol, sendok, pisau, dan lemari pendingin.

\subsection{Bahan}

Bahan yang digunakan pada praktikum ini yaitu air kelapa tua, belimbing wuluh, air mineral, gula, aluminium foil, tissue, dan kapas .

\subsection{Prosedur Penelitian}

\subsubsection{Preparasi Ekstrak Belimbing Wulu}

Preparasi belimbing wuluh dilakukan dengan beberapa tahap, yaitu buah belimbing sebanyak 800 gr (keseluruhan) yang masih muda disortasi untuk memisahkan buah yang layak diolah dan yang tidak. Buah belimbing yang sudah disortir dan yang masih segar dibersihkan menggunakan air yang mengalir. Tahap selanjutnya yaitu pengecilan ukuran buah dengan pemotongan untuk dapat diolah dan kemudian menyimpannya kedalam wadah yang bersih. Belimbing yang sudah di potong-potong kemudian dimasukkan kedalam blender untuk dihancurkan. Belimbing yang sudah hancur kemudian disaring menggunakan penyaringan kasar (penyaring tepung) untuk memperoleh ekstrak belimbing wuluh. Hasil ekstraksi dari belimbing wuluh sebanyak 800 gr dihasilkan ekstrak sebanyak $400 \mathrm{ml}$. Kandungan yang terkandung dalam buah belimbing wuluh yaitu flavonoid dan triterpenoid. Penambahan belimbing wuluh kedalam minuman isotonik befungsi sebagai antioksidan bagi tubuh dan triterpenoid berfungsi untuk mencegah diabetes dan gangguan kulit akibat iritasi.

\subsubsection{Pembuatan Minuman Isotonik}

Pembuatan minuman isotonik dilakukan dengan menggunakan metode sterilisasi non-thermal secara aseptik. Proses pembuatannya dilakukan dengan beberapa tahap yaitu, preparasi air kelapa tua kemudian penambahan gula untuk memperoleh campuran 1, Proses selanjutnya yaitu penambahan ekstrak belimbing wuluh yang sudah dipreparasi pada tahap sebelumnya, kemudian disterilisasi menggunakan metode nonthermal dengan penyaringan bertingkat meliapore 0.5-0.1 mikron. Proses akhir dari produk minuman isotonik ini yaitu pembotolan yang dilakukan secara aseptik untuk memperoleh minuman isotonik yang aman dari kontaminan bakteri patogen. Adapun rincian dari proses pembuatan minuman isotonik ini yaitu :

\subsubsection{Preparasi Air Kelapa}

Air kelapa tua yang digunakan sebanyak 5 Liter $(5000 \mathrm{ml})$ secara keseluruhan yang dibagi menjadi $1000 \mathrm{ml}$ pada setiap pengujian. Air kelapa ini berasal dari buah kelapa yang matang optimal. Air kelapa diperoleh dari salah satu pasar tradisional di Makassar. Preparasi air kelapa dilakukan dengan memisahkan air kelapa dari buahnya kemudian disimpan kedalam wadah yang bersih dengan tetap menjaga kualitas air kelapa. Air kelapa yang sudah terpisah kemudian disaring menggunakan penyaringan kasar secara aseptik. 


\subsubsection{Penambahan gula kedalam air kelapa}

Air kelapa tua yang telah dipreparasi kemudian ditambahkan gula sesuai dengan standar konsumsi gula sehari-hari menurut World Health Organization (WHO) sebanyak 6-7\% dalam $100 \mathrm{ml}(26 \mathrm{kkal} / 100$ $\mathrm{ml}$ ) atau $10 \%$ dari total energi. Gula yang ditambahkan merupakan gula yang digunakan sehari-hari yang dikenal dalam dunia pangan dengan nama sukrosa. Penambahan gula kedalam air kelapa tua berfungsi untuk menggantikan gula alami yang hilang akibat umur kelapa.

\subsubsection{Penambahan Ekstrak Belimbing Wuluh Secara Aseptik}

Ekstrak belimbing wuluh yang telah dipreparasi sebanyak $400 \mathrm{ml}$ kemudian ditambahkan kedalam air kelapa tua yang sudah ditambahkan dengan gula pasir. Penambahan ekstrak belimbing wuluh pada minuman isotonik berfungsi sebagai penambah nilai gizi. Gizi yang terkandung dalam ekstrak belimbing wuluh yaitu kaya akan flavonoid dan triterpenoid yang baik untuk kesehatan.

\subsubsection{Sterilisasi Dengan Penyaringan Bertingkat Meliapore 0.5-0.1 Mikron \\ Produk minuman isotonik} disterilisasi dengan menggunakan penyaringan filtrat meliapore 0,5 mikron ke 0,1 mikron. Penggunaan filtrat meliapore 0,5 berfungsi untuk menghilangkan kotoran (partikel) yang terdapat pada minuman dan filtrate 0,1 berfungsi untuk menghilangkan mikroba pathogen yang terdapat pada lingkungan sekitar pembuatan minuman isotonik. Sterilisasi yang dilakukan merupakan tahap terakhir dari pembuatan minuman isotonik sebelum dilakukan pembotolan dan pengujian analisa.

\subsubsection{Pembotolan}

Proses pembotolan dilakukan setelah produk jadi, pembotolan dilakukan secara aseptik agar produk minuman tidak terkontaminasi dengan mikroba. Botol yang digunakan sebanyak kurang lebih 10 buah yang terbuat dari plastik yang sudah di sterilisasi menggunakan alkohol 95\% kemudian di keringkan di Laminar Flow agar botol tetap steril. Pembotolan bertujuan agar tampilan produk lebih menarik dan bertahan lama. Setelah proses pembotolan maka, produk dilakukan uji sesuai standar minuman isotonic.

\subsubsection{Pengamatan}

Pengamatan produk akan dilakukan selama 7 hari dengan melihat beberapa pertimbangan yaitu, kebersihan alat yang yang digunakan, kepercayaan tempat (Laboratorium) yang digunakan, serta kondisi dari produk yang akan dihasilkan.

Pengamatan yang dilakukan untuk mengetahui kualitas minuman isotonik dari air kelapa dan ekstrak belimbing wuluh, pada penelitian ini yaitu dilakukan beberapa pengujian seperti pengukuran $\mathrm{pH}$, total asam, kadar vitamin $\mathrm{C}$, total padatan terlarut, pengamatan visual dan uji organoleptik.

\subsubsection{Analisa Data}

Data yang diperoleh kemudian diolah menggunakan metode secara deskriptif kuantitatif.

\section{HASIL DAN PEMBAHASAN}

\subsection{Upaya Sterilisasi Produk}

Sterilisasi merupakan suatu cara untuk menjaga atau mendapatkan suatu kondisi bebas mikroba yang terdapat pada bahan yang digunakan atau alat yang digunakan. Sterilisasi pada bahan pangan atau alat yang digunakan dapat dilakukan dengan dua cara yaitu, sterilisasi secara thermal dan sterilisasi non-thermal. Perbedaan Sterilisasi secara thermal dan non-thermal yaitu, sterilisasi thermal dapat mengurangi nilai nutrisi yang terkandung pada bahan pangan yang diakibatkan oleh suhu yang tinggi selama proses sterilisasi berlangsung, sedangkan pada sterilisasi non-thermal prosesnya berlangsung secara rantai dingin sehingga kandungan nutrisi maupun zat 
fungsionalnya pada bahan pangan tetap terjaga.

Mikrofiltrasi merupakan salah satu proses dengan melewatkan umpan padamembran mikropori. Membran mikrofiltrasi dapat diaplikasikan dalam industri diantaranya pada sterilisasi dingin dari minuman dan bahan farmasi, penjernihan jus buah, wine, dan bir, air ultra murni pada industri semi konduktor, recovery logam, pengolahan limbah, fermentasi kontiniu, pemisahan emulsi minyak dan air.

Teknologi mikrofiltrasi pada pengolahan air kelapa adalah sebagai suatu proses sterilisasi dingin (cold sterilization) sehingga mampu mempertahankan karakteristik khasnya, termasuk nilai gizi dan cita rasanya.

Penelitian pembuatan minuman isotonik dilakukan dengan penyaringan bertingkat dari 0,5 ke 0,1 mikron. Penggunaan filter meliapore 0,5 mikron berfungsi untuk menghilangkan kotoran dan partikel fisik yang terdapat pada bahan yang disaring dan filter 0,1 mikron berfungsi untuk memisahkan mikroba pathogenic dan pembusuk yang terdapat pada bahan baku yang disaring.

\subsection{Air Kelapa Tua Sebagai Bahan Baku}

Pembuatan minuman isotonik berbahan baku air kelapa tua merupakan inovasi dalam pengembangan minuman isotonik. Setiap butir kelapa rata-rata mengandung $300 \mathrm{ml}$ air kelapa. Pemanfaatan air kelapatua seringkali hanya dibuang begitu saja, baik ke sungai atau parit pembuangan dan dapat menyebabkan pencemaran. Sebagai akibat pembuangan ini dapat terbentuk endapan berwarna hitam dan berbau tidak sedap. Apabila air kelapa dalam jumlah besar masuk ke sawah dapat mengakibatkan pertumbuhan yang tidak normal pada tanaman padi (Suhardiyono, 1999).

Air kelapa tua yang digunakan pada penelitian ini merupakan air kelapa tua matang optimal segar yang ditandai dengan buah kelapa yang tidak bertompong dan berbau khas air kelapa segar. Pemanfaatan air kelapa tua dalam pembuatan minuman isotonik berfungsi untuk memanfaatkan bahan pangan yang kurang dimanfaatkan dalam proses pengolahan pangan. Air kelapa tua diperoleh dari pedagang kelapa yanga ada dipasaran. Proses pengambilan air kelapa dilakukan secara rantai dingin aseptik dengan menjaga kualitas air kelapa selama penampungan hingga diolah menjadi minuman isotonik. Kandungan nutrisi yang terdapat pada air kelapa tua yaitu, mineral yang terdiri dari Kalium, Magnesium, Natrium dan beberapa nutrisi lainnya. Menurut (Warisno, 2004), air kelapa juga mengandung mineral seperti Kalium dan Natrium.

\subsection{Masa Simpan Produk}

Produk minuman isotonik ini diharapkan dapat dijadikan sebagai salah satu usaha rumah tangga yang dilakukan secara sederhana. Namun, produk ini tetap aman untuk kesehatan dan tidak mengandung mikroba pathogen. Produk minuman isotonik yang dihasilkan diamati masa simpannya pada suhu kamar bukan pada suhu dingin untuk mempercepat waktu pengamatan.

Faktor penyimpanan sebelum dikonsumsi memegang peranan penting untuk memperpanjang masa simpan produk menjadi lebih lama dengan mutu tetap baik makadilakukan cara pengendalian suhu selama penyimpanan. Ada tiga cara penyimpanan dingin berdasarkan perbedaan suhu yaitu suhukamar $\left(26-28^{\circ} \mathrm{C}\right)$, suhu rendah $\left(5-10^{\circ} \mathrm{C}\right)$ dan suhu beku (di bawah suhu $\left({ }^{\circ} \mathrm{C}\right)$. Semakin rendah suhu penyimpanan mengakibatkan daya simpannya bertambah lama (Winarno, 1992).

Bahan baku dari pembuatan minuman isotonik ini yaitu air kelapa tua dan belimbing wuluh. Air kelapa tua yang digunakan merupakan kelapa tua yang yang matang optimal. Proses penampungan air kelapa sekiranya dilakukan secara higienis dengan rantai dingin untuk menghindari pencemaran mikroorganisme 
pathogen dan mengurangi beban mikroba pembusuk. Pada proses penyimpanan terdapat dua produk hasil dari preparasi yang berbeda yaitu hasil filtrasi dan tanpa filtrasi. Pengamatan masa simpan produk dilakukan secara visual dengan melihat ada tidaknya aktivitas mikroba, terjadinya endapan dan terakumulasinya gas. Masa simpan kedua produk tersebut akan dibandingkan untuk melihat efektivitas perlakuan yang diberikan.

Hasil pengamatan menujukkan bahwa produk tanpa filtrasi memberikan umur simpan lebih pendek dibandingkan dengan produk hasil filtrasi. Pengamatan visual tersebut dilakukan pada hari kesatu, hari keempat, dan hari ketujuh. Penyimpanan tersebut dilakukan untuk melihat seberapa lama umur simpan dari produk. Semakin lama penyimpanan pada suhuruang/kamar akan mengakibatkan penurunan nilai $\mathrm{pH}$ dan kenaikan total asam. Oleh karena itu penelitian ini dilakukan untuk mengetahui pengaruh lama penyimpanan terhadap uji visualisai, nilai $\mathrm{pH}$, total asam, dan total padatan terlarut selama penyimpanan pada suhu kamar. Umur simpan yang di lakukan ditinjau dari aspek tingkat higienitas dan tempat penyimpanan.

\section{$3.4 \mathrm{pH}$}

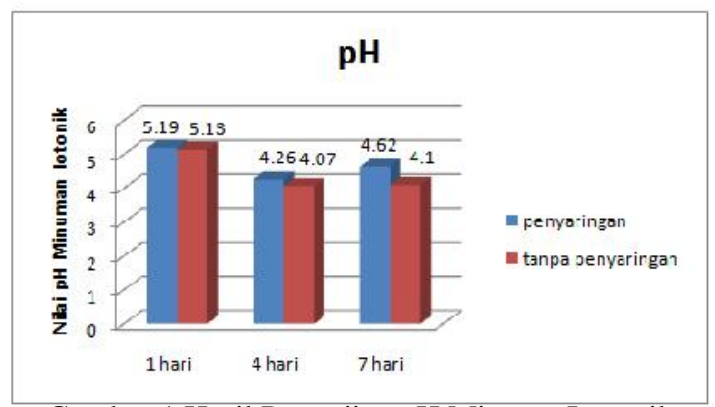

Gambar 1 Hasil Pengujian pH Minuma Isotonik.

Hasil pengujian pengukuran nilai $\mathrm{pH}$ yang dihasilkan dari produk minuman isotonik berbahan dasar air kelapa tua dan ekstrak belimbing wuluh menunjukkan perbedaan dari dua perlakuan. Perbandingan perlakuan pada hari ke satu penyaringan mendapatkan nilai 5,19 dan tanpa penyaringan mendapatkan nilai 5,13. Perbandingan perlakuan pada hari ke empat penyaringan mendapatkan nilai 4,26 dan tanpa penyaringan mendapatkan nilai 4,07. Perbandingan perlakuan pada hari ke tujuh penyaringan mendapatkan nilai 4,62 dan tanpa penyaringan mendapatkan nilai 4,1 . Berdasarkan data yang diperoleh dari hasil pengukuran nilai $\mathrm{pH}$ menunjukkan adanya penurunan dari hari pertama ke hari keempat dan mengalami kenaikan pada hari ketujuh. Penurunan nilai $\mathrm{pH}$ di hari pertama ke hari keempat diakibatkan minuman isotonik telah mengalami proses fermentasi air kelapa menjadi vinegar akan tetapi, selama proses fermentasi tersebut air kelapa akan mengalami tahapan yang awalnya akan membentuk alkohol. Sedangkan, kenaikan nilai $\mathrm{pH}$ di hari keempat ke hari ketujuh proses fermentasi air kelapa menjadi vinegar sempurna yang ditandai dengan nilai $\mathrm{pH}$. Proses fermentasi air kelapa akan dipengaruhi ion hidrogen yang akan dilepaskan menjadi alkohol dan penambahan gula sebanyak $7 \%$ yang akan mengkonversi gula menjadi alkohol. Hal ini sesuai dengan pernyataan (Kwartiningsih, E. dan Mulyati, 2005) yang menyatakan Vinegar merupakan produk fermentasi yang terjadi secara bertahap /suksesif. Menurut (Schlegel \& Schmid, 1994), nilai $\mathrm{pH}$ vinegar air kelapa dipengaruhi oleh jumlah ion hidrogen $(\mathrm{H}+)$ yang dilepaskan saat senyawa karbonteroksidasi menjadi alkohol, sebahagian ion hidrogen $(\mathrm{H}+)$ tersebut direduksi kembali membentuk senyawa asam asetat.

\subsection{Total Padatan Terlarut}

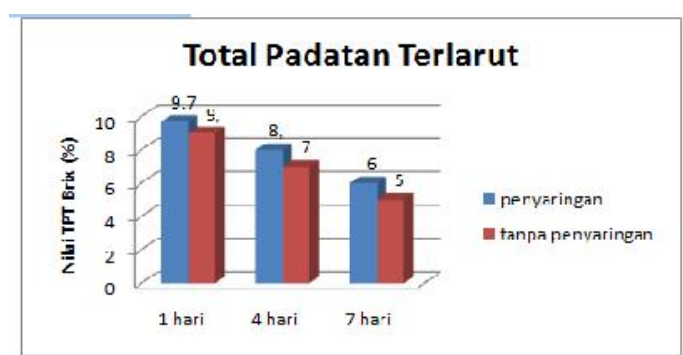

Gambar 2 Hasil Pengujian Total Padatan Terlarut Minuma Isotonik.

Hasil pengujian pengukuran total padatan terlarut yang dihasilkan dari produk minuman isotonik berbahan dasar 
air kelapa tua dan ekstrak belimbing wuluh menunjukkan perbedaan dari dua perlakuan. Perbandingan perlakuan pada hari pertama penyaringan mendapatkan nilai 9,7 dan tanpa penyaringan mendapatkan nilai 9,0. Perbandingan perlakuan pada hari keempat penyaringan mendapatkan nilai 8,0 dan tanpa penyaringan mendapatkan nilai 7,0.Perbandingan perlakuan pada hari ketujuh penyaringan mendapatkan nilai 6,0 dan tanpa penyaringan mendapatkan nilai 5,0. Berdasarkan data yang yang diperoleh dari hasil total padatan terlarut menunjukkan adanya penurunan dari hari pertama hingga hari ke tujuh. Pada hari pertama pengamatan didapatkan adanya perbedaan dari total padatan terlarut dari dua perlakuan. Perbedaan nilai total padatan terlarut diakibatkan adanya kesalahan preparasi pada saat proses pembuatan minuman isotonik. Kesalahan preparasi tersebut pada saat proses penambahan gula dan ekstrak belimbing wuluh kedalam air kelapa tua yang dipisah dari dua perlakuan sehingga nilai total padatan terlarut pada hari pertama berbeda. Penururnan nilai total padatan terlarut yang terdapat pada produk minuman isotonik disebabkan karena senyawa organik dan anorganik yang terlarut berupa gula yang akan terkonversi menjadi alkohol. Semakin tinggi konsentrasi gula dan lama fermentasimaka total padatan terlarut akan semakin menurun. Hal ini disebabkan karena semakin tinggi konsentrasi gula dan semakin lama fermentasi akan menghasilkan semakin banyak mikroba pada air kelapa tua yang digunakan. Gula yang yang terkandung dalam produk minuman isotonik merupakan gula pereduksi yang dapat larut sempurna dalam larutan. Hal ini sesuai dengan pernyataan (yuliani, 2008), yang meyatakan Mikroba yang terdapat pada minuman isotonik lebih banyak memanfaatkan substrat untuk proses metabolisme sehingga nilai total padatan terlarut semakin menurun.

\subsection{Total Asam}

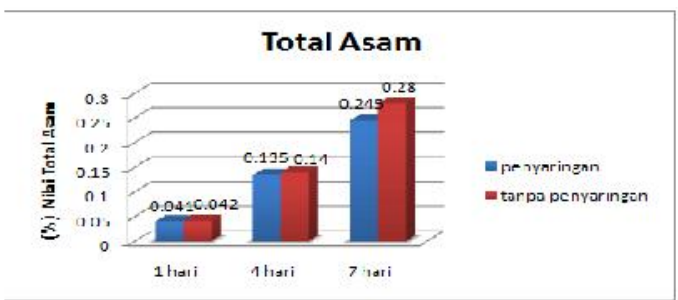

Gambar 3 Hasil Pengujian Total Asam Minuma Isotonik

Hasil pengujian pengukuran total asam yang dihasilkan dari produk minuman isotonik berbahan dasar air kelapa tua dan ekstrak belimbing wuluh menunjukkan perbedaan dari dua perlakuan. Perbandingan perlakuan pada hari pertama penyaringan mendapatkan nilai 0,041 dan tanpa penyaringan mendapatkan nilai 0,042 . Perbandingan perlakuan pada hari keempat penyaringan mendapatkan nilai 0,13 dan tanpa penyaringan mendapatkan nilai 0,14 . Perbandingan perlakuan pada hari ketujuh penyaringan mendapatkan nilai 0,24 dan tanpa penyaringan mendapatkan nilai 0,28. Berdasarkan data yang yang diperoleh dari hasil total asam menunjukkan adanya peningkatan dari hari pertama hingga hari ke tujuh. Peningkatan total asam yang terkandung dalam produk minuman isotonik berkaitan dengan penurunan nilai $\mathrm{pH}$. Total asam mengalami peningkatan dan $\mathrm{pH}$ menurun diakibatkan adanya aktivitas bakteri asam laktat yang dapat mengubah glukosa menjadi asam laktat sehingga, kandungan asam - asam organik akan mengalami peningkatan. Semakin tinggi konsentrasi gula dan lama fermentasi maka total asam semakin tinggi. Hal ini sesuai dengan pernyataan (Buckle \& Edward, 1987), yang menyatkan bahwa fermentasi asam laktat terjadi karena adanya aktivitas bakteri asam laktat yang mengubah glukosa menjadi asam laktat.

\subsection{Uji Visualisasi}

Pengujian visusalisasi pada produk minuman isotonik dilakukan disuhu kamar. Kerusakan minuman isotonik ditandai dengan terbentuknya endapan dan terakumulasinya gas selama penyimpanan. Terbentuknya endapan dan terakumulasinya 
gas diduga karena adanya aktivitas mikroba anaerobik termasuk bakteri asam laktat dan khamir dari bahan baku produk minuman isotonik.

\subsection{Pengujian Organoleptik}

\subsubsection{Warna}

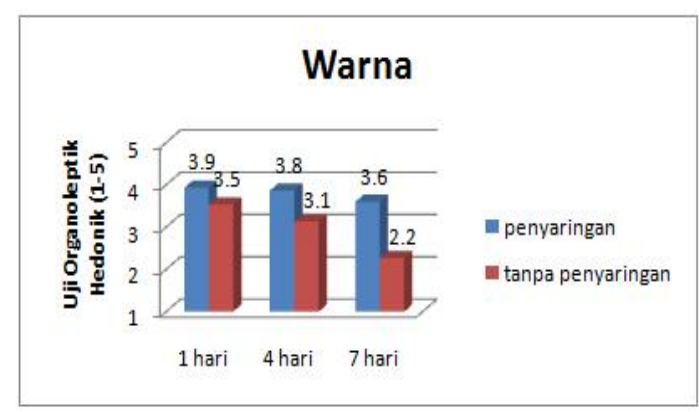

Gambar 4 Hasil Pengujian Organoleptik Warna Minuma Isotonik

Hasil pengujian organoleptik terhadap warna yang dihasilkan dari produk minuman isotonik berbahan dasar air kelapa tua dan ekstrak belimbing wuluh menunjukkan perbedaan dari dua perlakuan. Perbandingan perlakuan pada hari 1 penyaringan mendapatkan nilai 3,9 dan tanpa penyaringan mendapatkan nilai 3,5. Perbandingan perlakuan pada hari 4 penyaringan mendapatkan nilai 3,8 dan tanpa penyaringan mendapatkan nilai 3,1.Perbandingan perlakuan pada hari 7 penyaringan mendapatkan nilai 3,6 dan tanpa penyaringan mendapatkan nilai 2,2. Berdasarkan data yang diperoleh sesuai pada gambar 05 menunjukkan tingkat kesukaan panelis dari hari 1 hingga 7 pada parameter warna terlihat bahwa perlakuan dengan menggunakan penyaringan lebih tinggi dibandingkan dengan tanpa penyaringan. Proses penyaringan tidak mengubah warna produk dikarenakan alat penyaring yang digunakan tidak menyaring partikel pada bahan melainkan menahan mikroorganisme yang terdapat pada bahan baku yang digunakan. Penentuan warna pada produk pangan dapat berpengaruh terhadap kualitas produk yang dihasilkan dalam hal ini minuman isotonik.
Hal ini disebabkan oleh adanya penambahan ekstrak belimbing wuluh pada produk minuman isotoik yang memberikan warna pada produk. Proses ekstraksi dilakukan dengan memperkecil ukuran buah belimbing wuluh dan menghaluskannya. Belimbing wuluh yang dieksrtak menghasilkan warna yang lebih baik dibandingkan sebelum diekstrak. Belimbing wuluh yang umumnya berwarna hijau hingga hijau kekuningan akan tetap berwarna hijau meski telah diekstrak menjadi ekstrak belimbing. Warna hijau kekuningan yang terdapat pada belimbing wuluh berasal dari kandungan yang terdapat pada buah. Hal ini sesuai dengan pernyataan (Pino \& Febles, 2013).

yang menyatakan bahwa warna khas buah belimbing wuluh varietas hijau merupakan interaksi antara senyawa nonanal, asam nonanoat, dan (E)-2Nonenal. Sedangkan senyawa yang bertanggung jawab terhadap rasa pada buah belimbing wuluh adalah (Z)-3-heksenol.

\subsubsection{Aroma}

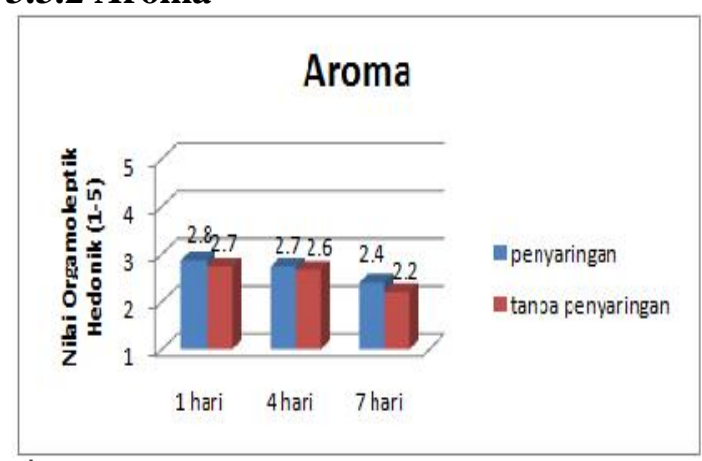

Gambar 5 Hasil Pengujian Organoleptik Aroma Minuma Isotonik.

Hasil pengujian organoleptik terhadap aroma yang dihasilkan dari produk minuman isotonik berbahan dasar air kelapa tua dan ekstrak belimbing wuluh menunjukkan perbedaan dari dua perlakuan. Perbandingan perlakuan pada hari 1 penyaringan mendapatkan nilai 2,8 dan tanpa penyaringan mendapatkan nilai 2,7. Perbandingan perlakuan pada hari 4 penyaringan mendapatkan nilai 2,7 dan tanpa penyaringan mendapatkan nilai 2,6. Perbandingan perlakuan pada hari 7 
penyaringan mendapatkan nilai 2,4 dan tanpa penyaringan mendapatkan nilai 2,2. Berdasarkan data yang diperoleh sesuai pada gambar 06 menunjukkan tingkat kesukaan panelis dari hari 1 hingga 7 pada parameter aroma terlihat bahwa perlakuan dengan menggunakan penyaringan lebih tinggi dibandingkan dengan tanpa penyaringan.

Aroma merupakan salah satu parameter untuk menentukan kualitas dari suatu produk. Pada umumnya, produk minuman memiliki aroma yang khas sesuai dengan bahan baku yang digunakan. Aroma pada minuman isotonik yang dihasilkan beraroma khas kelapa. Buah kelapa mengandung senyawa aromatik yaitu 2 asetil-1-pyrroline (2-AP) dan umumnya dikenal dengan nama 5-asetil-3,4-dihydro2Hpyrroline yang dimasukkan kedalam kelompok senyawa pirol. Hal ini sesuai dengan pernyatan (Jaroonchon, Krisanapook, \& Imsabai, 2017). yang menyatakan bahwa aroma yang kuat berasal dari formasi 2-AP danpaling banayk ditemukan pada buah kelapa

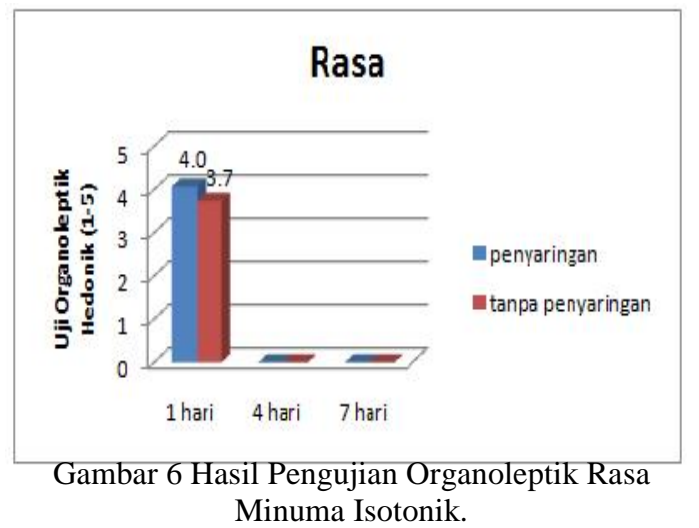

Hasil pengujian organoleptik terhadap rasa yang dihasilkan dari produk minuman isotonik berbahan dasar air kelapa tua dan ekstrak belimbing wuluh menunjukkan perbedaan dari dua perlakuan. Perbandingan perlakuan pada hari 1 penyaringan mendapatkan nilai 4,0 dan tanpa penyaringan mendapatkan nilai 3,7. Perlakuan pada hari 4 dan hari 7 tidak dilakukan pengujian organileptik rasa baik pada penyaringan maupun tanpa penyaringan dikarenakan produk telah mengalami penurunan mutu yang ditandai dengan terbentuknya endapan dan terakumulasi oleh gas. Hal ini disebabkan oleh adanya dugaan aktivias mikroba pada produk selama penyimpanan. Terakumulasinya gas pada produk diakibatkan proses fermentasi yang diakibatkan oleh air kelapa tua yang disimpan mengandung mikroba yang dapat mengubah air kelapa menjadi vinegar. Air kelapa yang tersimpan lama akan mengalami proses fermentasi yang akan menimbulkan alkohol. Hal ini sesuai dengan pernyataan (Mike, 2002), yang menyatakan air kelapa merupakan salah satu bahan yang sangat mungkin dapat digunakan untuk memproduksi vinegar. Menurut (Saputri, 2010), air kelapa berpotensi dijadikan bahan baku produk pangan, antara lain pembuatan minuman, jelly, alkohol, dekstran, nata de coco, kecap dan vinegar.

\section{KESIMPULAN}

Adapun kesimpulan yang diperoleh dari penelitian ini adalah :

1. Minuman isotonik berbahan baku air kelapa tua dan ekstrak belimbing merupakan salah satu minuman yang memiliki banyak kandungan nutrisi dimana air kelapa tua mengandung banyak mineral dibandingkan dengan air kelapa muda, kandungan mineral yang terkandung dalam air kelapa tua diantaranya, kalium, magnesium, dan fosfor selain kandungan mineral yang tinggi air kelapa tua juga mengandung hormone dan vitamin. Sedangkan belimbing wuluh merupakan salah satu buah yang memiliki banyak manfaat bagi tubuh karena mengandung senyawa flavonoid dan triterpenoid yang baik untuk kesehatan.

2. Produk minuman isotonik yang diperoleh beraroma khas air kelapa tua yang dipadukan dengan penambahan ekstrak belimbing wuluh. Hasil pengujian organoleptik produk minuman isotonik ini menunjukkan perlakuan dengan 
penyimpanan dapat berpengaruh terhadap kualitas dari produk minuman yang dihasilkan. Perlakuan dengan penyaring dan tanpa penyaring menujukkan tingkat kesukaan panelis berbeda-beda dari segi rasa, aroma, dan warna.

\section{DAFTAR PUSTAKA}

Buckle, \& Edward. (1987). Ilmu Pangan. Terjemahan Purnomo dan Adiono. Jakarta: Universitas Indonesia Press.

Fachruddin. (2002). embuat Aneka Sari Buah.Kansius. Yogyakarta.

Jaroonchon, N., Krisanapook, K., \& Imsabai, W. (2017). The development of 2 acetyl-1-pyrroline (2-AP) in thai aromatic coconut. Songklanakarin Journal of Science and Technology. https://doi.org/10.14456/sjstpsu.2017.21

Kwartiningsih, E. dan Mulyati. (2005). Pembuatan fruit leatherdari nenas. Ekuilibrum, 4, 8-12.

Mike. (2002). Green Chemistry, an Introductory Text. 262-266: Cambridge: Royal Society of Chemistry.

Pino, J. A., \& Febles, Y. (2013). Odouractive compounds in banana fruit $\mathrm{cv}$. Giant Cavendish. Food Chemistry. https://doi.org/10.1016/j.foodchem.20 13.03.064

Rindegan. (2004). Pembuatan dan Pemanfaatan Minyak Kelapa Murni. Jakarta: Penerbit Swadaya.

Riyana. (2002). Media Pembelajaran. Bandung. WacanaPrima.

Saputri. (2010). Hubungan Stress Dengan Hipertensi Pada Penduduk Indonesia Tahun 2007 (Analisis Data Riskesdas 2007). Universitas Indonesia.

sarmidi. (2009). Cocopreneurship Aneka Peluang Bisnis dari Kelapa. Yogyakarta: Lily Publisher.

Schlegel, \& Schmid. (1994). Microbiology Six Edition. (Terjemahan Mikrobiologi Umum edisi Keenam. Diterjemahkan Oleh Tedjo Baskoro). Yogyakarta: Gajah Mada University Press.
Suhardiyono. (1999). Tanaman Kelapa, Budidaya dan Pemanfaatannya. Yogyakarta: Kanisius.

Warisno. (2004). Mudah dan Praktis Membuat Nata de Coco. Jakarta: Media Pustaka.

Winarno. (1992). Kimia Pangan dan Gizi. Jakarta: gramedia Pustaka Utama.

Winarno. (2002). Kimia Pangan dan Gizi. Jakarta: PT. Gramedia Pustaka Utama. yuliani. (2008). Sintesis Ester Laktovanilit dari Asam Vanili dan Laktosa serta Uji Aktivitas Antioksidan. Universitas Indonesia, Jakarta. 